ISSN : 2615-1995, E-ISSN : 2615-0654

J. Madani., Vol. 1, No. 2, September 2018 (343-360)

(C)2018 Lembaga Kajian Demokrasi

MADANI

dan Pemberdayaan Masyarakat (LKD-PM)

\title{
PENGARUH CAPITAL ADEQUACY RATIO (CAR) DAN NON PERFORMING LOAN (NPL) TERHADAP PROFITABILITAS (STUDI KASUS PADA BANK BUMN)
}

\author{
Noryani \\ Fakultas Ekonomi, Universitas Pamulang \\ nuryanicasidy@yahoo.com
}

\begin{abstract}
Abstrak
Penelitian ini bertujuan untuk mengetahui pengaruh Capital Adequacy Ratio (CAR) dan Non Performing Loan (NPL) terhadap Return On Asset (ROA) pada Bank BUMN. Metode yang digunakan dalam penelitian ini menggunakan metode kuantitatif dengan menganalisis melalui perhitungan, menyajikan data berdasarkan variabel yang diteliti serta penjelasan perkembangan setiap variabel untuk menjawab rumusan masalah, dan pengolahan data dengan statistic guna menguji hipotesis. Alat analisis yang digunakan meliputi analisis deskriptif, uji asumsi klasik dan analisis statistik inferesial yaitu: 1. Analisis Regresi Linier Sederhana dan Berganda, 2. Koefisien Determinasi $\left(R^{2}\right)$, 3. Analisis Koefisien Korelasi, 4. Analisis Koefisien determinasi 5. Uji Hipotesis dengan Uji Parsial (uji t) dan Uji Simultan (uji F). Hasil Pengujian dan analisisnya adalah sebagai berikut :1.Tidak terdapat pengaruh signifikan antara Capital Adequacy Ratio (CAR) terhadap Return On Asset (ROA), dengan kontribusi pengaruh sebesar 7,0\%. Dan

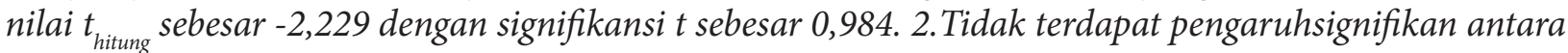
Non Performing Loan (NPL), dengan kontribusi pengaruh sebesar 5,2 Dan nilai $t_{\text {hitung }}$ sebesar -1,448 dengan signifikansi t sebesar 0,156. 3. Tidak terdapat pengaruh signifikan antara Capital Adequacy Ratio (CAR) dan Non Performing Loan (NPL) terhadap Return On Asset (ROA), dengan kontribusi pengaruh sebesar 10,7\%. Dan nilai $F_{\text {hitung }}$ sebesar 2,225 dengan signifikansi F sebesar 0,122.
\end{abstract}

Kata Kunci : Capital Adequacy Ratio, Non Performing Loan, Return On Asset

\section{PENDAHULUAN}

\section{Latar Belakang}

Bank merupakan lembaga intermediasi bagi pihak yang kelebihan dana dengan pihak yang kekurangan dana. Dimana bank memiliki beberapa fungsi, salah satunya adalah agent of trust. Agent of trust berarti dalam kegiatan usahanya bank mengandalkan kepercayaan (trust) masyarakat. Masyarakat percaya bahwa uangnya tidak akan disalahgunakan oleh bank, uangnya akan dikelola dengan baik dan bank tidak akan bangkrut (Sigit Triandaru dan Totok Budisantoso (2008).

Gejolak moneter dan krisis ekonomi yang terjadi di Indonesia, kebijakan makro ekonomi yang ketat terkait dengan kenaikan resiko dan tekanan inflasi.Kinerja perbankan di Indonesia menjadi menurun karena melambatnya pertumbuhan kredit dan potensi kenaikan kredit bermasalah. Belum efektif dan efisiennya penanganan krisis sistem keuangan pada bank BUMN. Kurangnya kesiapan bank BUMN dalam menghadapi Masyarakat Ekonomi Asean (MEA), merupakan beberapa permasalahan yang dihadapi oleh bank BUMN di Indonesia.

Keempat bank BUMN yakni Bank BRI, Mandiri, BNI, dan BTN berturut-turut merupakan bank terbesar nomor satu, dua, empat, 
dan enam dari total 118 bank di Indonesia. Per akhir 2015, total aset keempat Bank BUMN tersebut mencapai $\mathrm{Rp} 2.445,47$ triliun, atau 40 persen dari total aset industri perbankan nasional sebesar Rp6.132,58 triliun. Karena berposisi sebagai market leader dengan pangsa pasar yang besar, kinerja Bank BUMN sangat mempengaruhi kinerja perbankan nasional.

Berdasarkan laporan Badan Pusat Statistik (BPS), pertumbuhan ekonomi Indonesia selama triwulan I 2016 hanya 4,92 persen, melambat dibandingkan triwulan IV 2015 yang sebesar 5,04 persen. Karena sektor riil lesu, penyaluran kredit, termasuk oleh bank-bank BUMN pun melemah. Pertumbuhan kredit BRI, BNI, dan BTN per akhir Maret 2016 dibandingkan akhir tahun 2015 berturut-turut hanya 0,48 persen, 0,19 persen, dan 2,87 persen. Perbandingan menggunakan posisi akhir 2015 karena yang ingin dipotret hanyalah kinerja bank BUMN selama triwulan I 2016.

Kinerja keuangan suatu perusahaan dapat dinilai menggunakan beberapa alat analisis keuangan diantaranya dengan menggunakan rasio profitabilitas. Rasio profitabilitas merupakan salah satu rasio keuangan yang dapat digunakan untuk mengukur efektivitas perusahaan dalam memperoleh laba, atau dengan kata lain profitabilitas merupakan rasio yang menunjukkan kemampuan perusahaan untuk menghasilkan laba dari kegiatan operasionalnya (Munawir,2002). Profitabilitas dalam dunia perbankan dapat dihitung dengan Return on Assets (selanjutnya disingkat ROA). Dalam hal ini Return On Asset (ROA) merupakan rasio antara laba sebelum pajak terhadap total asset. ROA penting bagi bank karena ROA digunakan untuk mengukur efektivitas perusahaan dalam menghasilkan keuntungan dengan memanfaatkan asset yang dimilikinya. Menurut ketentuan Bank Indonesia, standar yang paling baik untuk Return On Assets dalam ukuran bank-bank Indonesia minimal 1,5\%. Semakin besar ROA suatu bank, semakin besar pula tingkat keuntungan yang dicapai bank tersebut dan semakin baik pula posisi bank tersebut dari segi penggunaan asset (Lukman Dendawijaya, 2000).

Capital Adequacy Ratio merupakan rasio permodalan yang menunjukkan kemampuan bank dalam menyediakan dana untuk keperluan pengembangan usaha serta menampung kemungkinan resiko kerugian yang diakibatkan dalam operasional bank. Semakin besar rasio tersebut akan semakin baik posisi modal (Achmad dan Kusuno, 2003:50). Menurut Peraturan Bank Indonesia Nomor 10/15/PBI/2008 pasal 2 ayat 1 tercantum bank wajib menyediakan modal minimum sebesar 8\% dari Aset Tertimbang Menurut Resiko (ATMR). Hal ini diperbaharui lebih detail melalui peraturan Bank Indonesia Nomor 15/12/PBI/2013 pasal 2 ayat 3 tercantum bank wajib menyediakan modal minimum sebesar 8\% dari Aset Tertimbang Menurut Resiko (ATMR) untuk Bank dengan profil resiko peringkat 1 (satu). CAR adalah rasio yang memperlihatkan seberapa besar jumlah seluruh aktiva bank yang mengandung resiko (kredit, penyertaan, surat berharga, tagihan pada bank lain) ikut dibiayai dari modal sendiri disamping memperoleh dana-dana dari sumber-sumber diluar bank seperti dana dari masyarakat (Dendawijaya, 2005:121).

NPL adalah rasio keuangan yang digunakan sebagai proksi terhadap tingkat pengembalian kredit yang diberikan deposan kepada bank dengan kata lain NPL merupakan tingkat kredit macet pada bank tersebut. Rasio ini menunjukkan bahwa kemampuan manajemen bank dalam mengelola kredit bermasalah yang diberikan oleh bank. Semakin kecil Non Performing Loan (NPL), maka semakin kecil pula resiko kredit yang ditanggung oleh pihak bank.

Nilai ROA yang fluktuatif pada beberapa bank umum di Indonesia dipengaruhi oleh beberapa faktor lainnya. Dimana faktor-faktor ini juga dapat digunakan dalam penilaian kinerja maupun laba yang diperoleh bank seperti, CAR (mewakili modal), NPL (mewakili resiko kredit).

Beberapa penelitian terdahulu menunjukkan adanya faktor-faktor yang mempengaruhi ROA namun terjadi ketidakkonsistenan dalam penelitian tersebut, seperti: CAR yang diteliti Yuliani (2007) menemukan bahwa CAR mempunyai hubungan dengan kinerja profitabilitas ROA. Sedangkan penelitian yang dilakukan oleh Sudarini (2005) menunjukkan bahwa Capital Adequacy Ratio (CAR) tidak berpengaruh terhadap ROA dan tidak signifikan terhadap Return on Assets (ROA).

Penelitian yang dilakukan oleh Wisnu Mawardi (2005) menunjukkan bahwa Non Per- 
forming Loan (NPL) berpengaruh negatif dan signifikan terhadap Return on Assets (ROA). Hal ini berbeda dengan hasil penelitian yang dilakukan oleh Sudarini (2005) yang menunjukkan bahwa Non Performing Loan (NPL) berpengaruh tidak signifikan terhadap perolehan laba Return on Assets (ROA).

Berdasarkan uraian pada latar belakang yang dikemukakan di atas, maka penulis tertarik untuk melakukan penelitian dengan memilih judul "Pengaruh Capital Adequacy Ratio (CAR) dan Non Performing Loan (NPL) Terhadap Return on Assets (ROA) Pada Bank BUMN".

\section{Pembatasan Masalah}

Dengan keterbatasan peneliti dan agar lebih dimengerti serta memudahkan maka penelitian inipenulis memberikan batasan-batasan untuk memfokuskan permasalahan yang akan diteliti, yaitu mengenai Capital Adequacy Ratio (CAR), Non Performing Loan (NPL) dan Return on Assets (ROA) pada Bank BUMN dengan data laporan keuangan periode tahun 2006-2015 yang dibuat dalam data panel disesuaikan dengan tingkat kebutuhan penulis.

\section{Perumusan Masalah}

Berdasarkan identifikasi dan pembatasan masalah di atas, maka untuk mencegah terjadinya kerancuan dalam pembahasan, perlu penulis berikan suatu perumusan masalah sebagai berikut :

1. Bagaimana pengaruh secara parsial antara CAR terhadap laba pada Bank BUMN.

2. Bagaimana pengaruh secara parsial antara NPL terhadap laba pada Bank BUMN.

3. Bagaimana pengaruh secara simultan antara CAR dan NPL terhadap laba pada Bank BUMN.

\section{Tujuan Penelitian}

Tujuan penelitian ini adalah :

1. Untuk mengetahui pengaruh secara parsial antara CAR terhadap laba pada Bank BUMN.

2. Untuk mengetahui pengaruh secara parsial antara NPL terhadap laba pada Bank BUMN.

3. Untuk mengetahui pengaruh secara simultan antara CAR dan NPL terhadap laba pada Bank BUMN.

\section{Tinjauan Teoritik}

\section{Manajemen}

Secara etimologis manajemen bisa diartikan sebagai seni mengatur dan melaksanakan. Kata manajemen sering digunakan dalam seharihari dan sangat membantu dalam mengerjakan sesuatu. Tentunya peran manajemen ini berfungsi agar segala pekerjaan dapat terselesaikan dengan baik secara tersistematis.

Menurut George R. Terry (2003) bahwasanya manajemen adalah ilmu sekaligus seni, manajemen adalah wadah di dalam ilmu pengetahuan, sehingga manajemen mampu dibuktikan secara umum kebenarannya. Sedangkan menurut Malayu S.P Hasibuan (2003) Manajemen adalah ilmu dan seni mengatur pemanfaatan sumber daya manusia dan sumber-sumber lainnya secara efektif dan efisien untuk mencapai suatu tujuan tertentu. Sedangkan menurut M.Manullang (2004) manajemen didefinisikan seni ilmu perencanaan, pengorganisasian, penyusunan, pengarahan dan pengawasan untuk mencapi tujuan yang sudah ditetapkan.

Dari beberapa pengertian manajemen maka dapat disimpulkan bahwa manajemen mempunyai tujuan yang telah ditetapkan sebelumnya. Tujuan ini yang akan menjadi sasaran yang hendak dicapai melalui kegiatan yang telah diatur manajemen untuk pencapaian tujuan organisasi.

\section{Manajemen Keuangan}

Menurut Agus Sartono (2008) Manajemen keuangan dapat diartikan sebagai manajemen dana baik yang berkaitan dengan pengalokasian dana dalam berbagai bentuk investasi secara efektif maupun usaha pengumpulan dana untuk pembiayaan investasi atau pembelanjaan secara efisien. Sedangkan menurut Martono dan Agus Harjito (2010) Manajemen keuangan adalah segala aktivitas perusahaan yang berhubungan dengan bagaimana memperoleh dana, menggunakan dana, dan mengelola asset sesuai tujuan perusahaan secara menyeluruh.

Bambang Riyanto (2011) menjelaskan bahwa keseluruhan aktivitas yang bersangkutan dengan usaha untuk mendapatkan dana dan menggunakan atau mengalokasikan dana tersebut adalah pengertian dari manajemen keuangan. Dari beberapa pengertian tersebut dapat ditarik kesimpulan bahwa manajemen 
keuangan adalah manajemen (pengelolaan) mengenai bagaimana memperoleh aset, mendanai aset dan mengelola asset untuk mencapai tujuan.

Menurut Jaja Suteja (2012) secara umum manajemen keuangan didefinisikan sebagai seni dan ilmu dalam mengelola uang (the art and science of managing money). Sedangkan menurut Darsono Prawironegoro (2007:25), Manajemen keuangan adalah "Aktivitas pemilik dan manajemen perusahaan untuk memperoleh modal yang semurah-murahnya dan menggunakan seefektif, seefisien dan seproduktif mungkin untuk menghasilkan laba".

Dari beberapa pengertian tersebut diatas dapat ditarik kesimpulan bahwa manajemen keuangan adalah manajemen (pengelolaan) mengenai bagaimana memperoleh aset, mendanai aset dan mengelola aset untuk mencapai tujuan perusahaan. Bagaimana cara mengelola fungsi-fungsi keuangan yang meliputi bagaimana memperoleh dana (raising of fund) dan bagaimana menggunakan dana tersebut (allocation of fund). Dalam hal ini manajer keuangan berkepentingan dengan penentuan jumlah aktiva yang layak dari investasi pada berbagai aktiva dan pemilihan sumber-sumber dana untuk membelanjai aktiva tersebut

\section{Bank}

Istilah bank bukan hal yang asing dalam pembicaraan masyarakat pada saat ini. Pada umumnya masyarakat mendefinisikan bank adalah tempat untuk menyimpan atau menabung dan meminjam dana. Menurut Undang-Undang RI nomor 10 tahun 1998 tentang perbankan, yang dimaksud dengan bank adalah badan usaha yang menghimpun dana dari masyarakat dalam bentuk simpanan dan menyalurkannya kepada masyarakat dalam bentuk kredit dan atau bentuk-bentuk lainnya dalam rangka meningkatkan taraf hidup rakyat banyak.

Menurut Kasmir (2011) Bank merupakan perusahaan keuangan yang bergerak dalam memberikan layanan keuangan yang mengandalkan kepercayaan dari masyarakat dalam mengelola dananya, sedangkan menurut Sigit Triandaru dan Totok Budisantoso (2008) menyatakan bahwa bank secara sederhana dapat diartikan sebagai lembaga keuangan yang kegiatan utamanya adalah menghimpun dana dari masyarakat baik secara langsung berupa tabungan, giro dan deposito maupun secaratidak langsung berupa kertas berharga; penyertaan dan sebagainya yang kemudian menyalurkan kembali dana tersebut ke masyarakat serta memberikan jasa bank lainnya.

\section{Rasio Keuangan}

Rasio keuangan adalah hasil perhitungan antara dua macam data keuangan bank, yang digunakan untuk menjelaskan hubungan antara kedua data keuangan tersebut yang pada umumnya dinyatakan secara numerik, baik dalam presentase atau kali. Hasil perhitungan rasio ini dapat digunakan untuk mengukur kinerja keuangan bank pada periode tertentu, dan dapat dijadikan tolok ukur untuk menilai tingkat kesehatan bank selama periode keuangan tersebut Slamet Riyadi (2006). Sedangkan menurut Munawir (2007) analisis rasio suatu metode untuk mengetahui hubungan dari pos-pos tertentu dalam neraca atau laba rugi secara individu atau kombinasi dari kedua laporan tersebut.

Rasio keuangan perbankan yang sering diumumkan dalam neraca publikasi biasanya meliputi rasio permodalan yaitu Capital Adequacy Ratio (CAR), Aktiva Produktif yaitu Aktiva Produktif Bermasalah, Non Performing Loan (NPL), PPAP terhadap Aktiva Produktif dan Pemenuhan PPAP; rasio rentabilitas yaitu Return On Assets (ROA), Return On Equity (ROE), Net Interest Margin (NIM), Beban Operasional Termasuk Beban Bunga dan Beban PPAP serta Beban Penyisihan Aktiva Lainlain Dibagi Pendapatan Operasional termasuk Pendapatan Bunga (BOPO); rasio Likuiditas yaitu Cash Ratio dan Loan To Deposit ratio (LDR).

Menurut Robert Anggoro (2009) rasio keuangan dapat dikelompokkan menjadi 5 jenis berdasarkan ruang lingkup atau tujuan yang akan dicapai, yaitu :

a. Rasio Profitabilitas adalah perbandingan laba (setelah pajak) dengan Modal (Modal Inti) atau Laba (Sebelum Pajak) dengan total asset yang dimiliki bank pada periode tertentu. Rasio ini mengukur kemampuan perusahaan menghasilkan keuntungan pada tingkat penjualan, aset, dan modal saham tertentu.

b. Rasio Likuiditas adalah rasio yang mengu- 
kur kemampuan perusahaan memenuhi kemampuan jangka pendek dengan melihat besarnya aktiva lancar relatif terhadap hutang lancarnya. Hutang dalam hal ini merupakan kewajiban perusahaan.

c. Rasio Aktivitas, Rasio ini melihat seberapa besar efisiensi penggunaan aset, termasuk dana yang tertanam pada asset perusahaan. Jika dana yang tertanam pada asset tertentu cukup besar, sementara dana tersebut mestinya bisa dipakai untuk investasi pada asset lain yang lebih produktif, maka profitabilitas perusahaan tidak sebaiknya yang seharusnya.

d. Rasio Solvabilitas/Leverage/hutang adalah rasio yang mengukur kemampuan perusahaan memenuhi kewajiban jangka panjangnya. Perusahaan yang tidak solvable adalah perusahaan yang total hutangnya lebih besar dibandingkan total assetnya.

e. Rasio pasar adalah rasio yang mengukur harga pasar saham perusahaan, relatif terhadap nilai bukunya. Sudut pandang rasio ini lebih banyak berdasar pada sudut pandang investor atau calon investor. Meskipun pihak manajemen juga berkepentingan terhadap rasio-rasio ini.

\section{Capital Adequacy Ratio (CAR)}

Modal merupakan sumber dana pihak pertama, yaitu sejumlah dana yang diinvestasikan oleh pemilik untuk pendirian suatu bank. Jika bank tersebut sudah beroperasi maka modal merupakan salah satu faktor yang sangat penting bagi pengembangan usaha dan menampung resiko kerugian. Agar perbankan dapat berkembang secara sehat dan mampu bersaing dalam perbankan internasional maka permodalan bank harus senantiasa mengikuti ukuran yang berlaku secara internasional, yang ditentukan oleh Banking for International Settlements (BIS), yaitu sebesar Capital Adequacy Ratio (CAR) adalah 8\%. (Slamet Riyadi, 2006).

CAR memperlihatkan seberapa jauh seluruh aktiva bank yang mengandung resiko (kredit, penyertaan, surat berharga, tagihan pada bank lain) ikut dibiayai dari dana modal sendiri bank disamping memperoleh dana-dana dari sumber-sumber diluar bank, seperti dana masyarakat, pinjaman (utang), dan lain-lain. Dengan kata lain, capital adequacy ratio adalah rasio kinerja bank untuk mengukur kecukupan modal yang dimiliki bank untuk menunjang aktiva yang mengandung atau menghasilkan resiko, misalnya kredit yang diberikan (Lukman Dendawijaya, 2000). Rumus dalam mencari nilai CAR adalah sebagai berikut:

\section{Non Performing Loan (NPL)}

NPL adalah tingkat pengembalian kredit yang diberikan deposan kepada bank dengan kata lain NPL merupakan tingkat kredit macet pada bank tersebut. NPL diketahui dengan cara menghitung Pembiayaan Non Lancar Terhadap Total Pembiayaan. Apabila semakin rendah NPL maka bank tersebut akan semakin mengalami keuntungan, sebaliknya bila tingkat NPL tinggi bank tersebut akan mengalami kerugian yang diakibatkan tingkat pengembalian kredit macet. Peningkatan Non Performing Loans (NPL) yang terjadi pada masa krisis secara langsung berpengaruh terhadap menurunnya likuiditas bagi sektor perbankan, karena tidak ada uang masuk baik yang berupa pembayaran pokok ataupun bunga pinjaman dari kredit-kredit yang macet. Sehingga bila hal ini dibiarkan maka akan berpengaruh terhadap hilangnya kepercayaan masyarakat. Adapun rumus yang digunakan adalah sebagai berikut:

\section{$\mathrm{NPL}=\frac{\text { KREDIT BERMASALAH }}{\text { TOTAL KREDIT }} \times 100 \%$}

Besarnya NPL yang diperbolehkan oleh Bank Indonesia saat ini adalah maksimal 5\%, jika melebihi 5\% maka akan mempengaruhi penilaian Tingkat Kesehatan Bank yang bersangkutan, yaitu akan mengurangi nilai/skor yang diperolehnya. Semakin besar tingkat NPL ini menunjukkan bahwa bank tersebut tidak profesional dalam pengelolaan kreditnya, sekaligus memberikan indikasi bahwa tingkat resiko atas pemberian kredit pada bank tersebut cukup tinggi searah dengan tingginya NPL yang dihadapi bank (Slamet Riyadi, 2006).

\section{Laba (Profutabilitas)}

Profitabilitas atau disebut dengan rentabilitas adalah kemampuan suatu perusahaan untuk menghasilkan laba selama periode tertentu. Rentabilitas perusahaan menunjukkan perbandingan antara laba dengan aktiva atau modal yang menghasilkan laba tersebut. Profitabilitas pada bank diukur dengan ROA yang 
mengukur kemampuan manajemen bank dalam memperoleh keuntungan (laba) secara keseluruhan (Lukman Dendawijaya, 2000). ROA adalah rasio yang digunakan mengukur kemampuan bank menghasilkan keuntungan secara relatif dibandingkan dengan total assetnya.

Rasio ini mengukur kemampuan perusahaan menghasilkan laba bersih berdasarkan tingkat aset yang tertentu. ROA merupakan perkalian antara Net Profit Margin dengan perputaran aktiva. Net Profit Margin menunjukkan kemampuan memperoleh laba dari setiap penjualan yang diciptakan oleh perusahaan. Sedangkan perputaran aktiva menunjukkan seberapa jauh perusahaan mampu menciptakan penjualan dari aktiva yang dimilikinya. Apabila kedua faktor itu meningkat maka ROA juga akan meningkat. Apabila ROA meningkat maka profitabilitas perusahaan meningkat sehingga dampak akhirnya adalah peningkatan profitabilitas yang dinikmati oleh pemegang saham. Rumus yang digunakan adalah sebagai berikut:

$$
\mathrm{ROA}=\frac{\text { LABA SEBELUM PAJAK }}{\text { TOTAL ASSET }} \times 100 \%
$$

\section{Hipotesis Penelitian}

Menurut Sugiyono (2014) Hipotesis adalah jawaban sementara terhadap rumusan masalah. Karena sifatnya masih sementara, maka perlu dibuktikan kebenarannya melalui data empirik yang terkumpul.

Adapun Hipotesis yang penulis ajukan adalah sebagai berikut:

H1 : Diduga terdapat pengaruh yang signifikan secara parsial antara Capital Adequacy Ratio (CAR) terhadap Return On Asset (ROA) pada Bank BUMN.

$\mathrm{H} 2$ : Diduga terdapat pengaruh yang signifikan secara parsial antara Non Performing Loans (NPL) terhadap Return On Asset (ROA) pada Bank BUMN.

H4 : Diduga terdapat pengaruh yang signifikan antara secara simultan Capital Adequacy Ratio (CAR) dan Non Performing Loans (NPL) terhadap Return On Asset (ROA) pada Bank BUMN.

\section{METODOLOGI PENELITIAN \\ Populasi dan Sampel}

Adapun populasi dalam penelitian ini adalah data berupa laporan keuangan pada Bank BUMN. Teknik yang digunakan dalam penarikan sampel menggunakan teknik non probability sampling. Non probability sampling. Adapun yang dijadikan sampel dalam penelitian ini adalah Laporan neraca dan Laba/Rugi Bank UMN periode 2006-2015.

\section{Variabel Penelitian}

Dalam penelitian ini terdapat tiga variabel, yaitu variabel independen, variabel dependen dan variabel moderating, seperti berikut :

1. Variabel bebas (independent variable) Variabel bebas yang dalam hubungannya dengan variabel lain bertindak sebagai penyebab atau yang mempengaruhi variabel dependen. Pada penelitian ini sebagai variabel independen yakni Capital Adequacy Ratio (CAR) dan Non Performing Loan (NPL). Variabel independen sering disebut sebagai predictor yang dilambangkan dengan $\mathrm{X}$.

2. Variabel terikat (dependent variable) Variabel yang tergantung dengan variabel lain, atau variabel yang dapat dipengaruhi oleh variabel lain. Sering disebut variabel respon di mana dalam penelitian ini adalah Return On Assets (ROA) yang dilambangkan dengan Y.

\section{Definisi Operasional Variabel}

Menurut Sugiyono (2014) menjelaskan bahwa variabel penelitian adalah suatu atribut atau sifat atau nilai dari orang, objek atau kegiatan yang mempunyai variasi tertentu yang ditetapkan oleh peneliti untuk dipelajari dan kemudian ditarik kesimpulannya. Variabel penelitian adalah objek penelitian atau sesuatu yang menjadi titik perhatian. Pengertian operasional variabel ini kemudian diuraikan menjadi indikator empiris yang meliputi :

\section{Capital Adequacy Ratio (CAR)}

Capital Adequacy Ratio (CAR) sebagai variabel bebas $\left(\mathrm{X}^{1}\right)$, CAR sebagai indikator permodalan yaitu rasio kecukupan modal minimum pada bank. Merupakan rasio yang memperlihatkan seberapa jumlah seluruh aktiva bank mengandung resiko (kredit, penyertaan, surat berharga, tagihan pada bank 
lain) ikut dibiayai dari modal sendiri disamping memperoleh dana-dana dari sumber-sumber di luar bank. Dalam penelitian ini adalah CAR pada laporan keuangan tahunan bank yang dipublikasikan selama periode 2006-2015. Pada penelitian ini CAR dihitung menggunakan rasio antara jumlah modal terhadap aktiva tertimbang menurut resiko (ATMR). Besarnya CAR dirumuskan sebagai berikut :

$$
\mathrm{CAR}=\frac{\text { MODAL }}{\mathrm{ATMR}}
$$

\section{Non Performing Loan (NPL)}

Non Performing Loan (NPL) sebagai variabel bebas $\left(\mathrm{X}^{2}\right)$, yaitu rasio antara kredit bermasalah dengan kredit yang disalurkan. NPL merupakan rasio yang dipergunakan untuk mengukur kemampuan bank dalam mengcover resiko kegagalan pengembalian kredit oleh debitur ( Komang Darmawan, 2004:243). Rasio ini menunjukkan kemampuan manajemen bank dalam mengelola kredit bermasalah yang diberikan oleh bank. Kredit dalam hal ini adalah kredit yang diberikan kepada pihak ketiga tidak termasuk kredit kepada bank lain. Kredit bermasalah adalah kredit dengan kualitas kurang lancar, diragukan, dan macet. Rasio NPL yang baik adalah dibawah 5\%, dan dirumuskan sebagai berikut :

$$
N P L=\frac{\text { KREDIT BERMASALAH }}{\text { TOTAL KREDIT }}
$$

\section{Return On Assets (ROA)}

Return On Assets (ROA) merupakan variabel moderator (Y). Variabel Moderator merupakan variabel yang mempengaruhi hubungan antara variabel independen dengan dependen, atau sering disebut sebagai variabel independen kedua. Return on assets merupakan salah satu rasio profitabilitas yang digunakan untuk mengukur efektifitas perusahaan di dalam menghasilkan laba dengan memanfaatkan total asset yang dimilikinya. ROA merupakan rasio antara laba sebelum pajak terhadap total asset bank tersebut. Semakin besar nilai ROA maka semakin baik besar pula kinerja perusahaan, karena return yang didapat perusahaan semakin besar. Dalam penelitian ini adalah ROA pada laporan keuangan bank yang dipublikasikan periode 2006-2015. ROA dihitung dengan rumus sebagai berikut :

$$
\mathrm{ROA}=\frac{\text { LABA SEBELUM PAJAK }}{\text { TOTAL ASSET }} \times 100 \%
$$

\section{Metode Pengumpulan Data}

\section{Observasi}

Metode ini dipergunakan untuk mendapatkan data primer kuantitatif, dilakukan dengan cara penulis langsung mendatangi perusahaan pada bagian keuangan guna mendapatkan data berupa laporan keuangan perusahaan yaitu laporan neraca dan laporan rugi/ laba periode tahun 20010-2015 yang oleh penulis dibuat data panel, serta untuk memperoleh gambaran obyek yang diteliti yang nantinya akan dapat digunakan untuk tambahan dalam melakukan analisis.

\section{Studi Pustaka}

Untuk mendapatkan data sekunder penulis melakukan dengan cara penelahaan terhadap literature-literature berupa buku-buku kuliah dan data yang diperoleh dalam bentuk yang sudah jadi, sudah diolah oleh pihak lain biasaya dalam bentuk publikasi serta bahan-bahan yang berhubungan dengan masalah yang berkaitan dengan penelitian ini.

\section{Metode Analisis Data}

Metode analisis data yang digunakan dalam penelitan ini adalah:

\section{Uji Asumsi Klasik}

Uji asumsi klasik digunakan untuk mengetahui ketepatan sebuah data. Menurut Singgih Santoso (2011) berpendapat "Sebuah model regresi akan digunakan untuk melakukan peramalan, sebuah model yang baik adalah model dengan kesalahan peramalan yang seminimal mungkin. Karena itu, sebuah model sebelum digunakan seharusnya memenuhi beberapa asumsi, yang biasa disebut asumsi klasik". Dalam penelitian ini uji asumsi klasik yang digunakan adalah meliputi: Uji Normalitas, Uji Multikolinearitas, Uji Autokorelasi, dan Uji Heterokedastisitas

\section{a. Uji Normalitas}

Uji normalitas digunakan untuk menguji apakah dalam sebuah model regresi, variabel dependen, variabel independen, atau keduanya mempunyai distribusi normal atau tidak. Menurut Ghozali (2013) berpendapat "Model 
regresi yang baik adalah berdistribusi normal atau mendekati normal". Jadi uji normalitas bukan dilakukan pada masing-masing variabel tetapi pada nilai residualnya. Dengan demikian uji ini untuk memeriksa apakah data yang berasal dari populasi terdistribusi normal atau tidak. Uji normalitas dapat berpedoman pada uji Kolmogorov Smirnov dengan ketentuan sebagai berikut :

1). Jika nilai signifikansi $<0,05$ (taraf kepercayaan 95\%), maka data tidak berdistribusi normal.

2). Jika nilai signifikansi $>0,05$ (taraf kepercayaan 95\%), maka data berdistribusi normal.

\section{b. Uji Multikolinieritas}

Uji Multikoliniearitas ini bertujuan menguji apakah pada model regresi ditemukan adanya korelasi antar variabel independen. Menurut Ghozali (2013), berpendapat bahwa "Uji multikolinearitas bertujuan untuk menguji apakah pada model regresi ditemukan adanya korelasi antar variabel bebas (independen)". Model regresi yang baik seharusnya tidak terjadi korelasi di antara variabel independen. Jika variabel independen saling berkorelasi, maka variabel-variabel ini tidak ortogonal. Variabel ortogonal adalah variabel independen yang nilai korelasi antar sesama variabel independen sama dengan nol. Untuk mendeteksi ada tidaknya multikoliniearitas dalam model regresi dapat dilihat dari tolerance value atau Variance Inflation Factor (VIF) dengan ketentuan sebagai berikut:

1) Jika nilai nilai tolerance lebih $>$ dari 0.1 dan nilai Variance Inflation Factor (VIF) < dari 10 , maka tidak terjadi multikolinieritas.

2) Jika nilai nilai tolerance lebih $<$ dari 0.1 dan nilai Variance Inflation Factor (VIF) $>$ dari 10, maka terjadi multikolinieritas.

\section{c. Uji Autokorelasi}

Uji autokorelasi digunakan untuk mengetahui ada atau tidaknya penyimpangan asumsi klasik autokorelasi, yaitu adanya korelasi antar anggota sampel. Menurut Ghozali (2013) Uji autokorelasi bertujuan menguji apakah dalam model regresi liner ada korelasi antar kesalahan pengganggu pada periode $t$ dengan kesalahan pengganggu pada periode $\mathrm{t}-1$.

Autokorelasi muncul karena observasi yang berurutan sepanjang waktu berkaitan satu sama lainnya. Masalah ini timbul karena residual tidak bebas dari satu observasi ke observasi lainnya. Model regresi yang baik adalah regresi yang bebas dari autokorelasi. Cara yang dapat digunakan untuk menditeksi ada atau tidaknya autokorelasi dalam penelitian ini yaitu dengan uji Durbin-Watson (DW test) dengan berpedoman pada kriteria pedoman sebagai berikut:

\begin{tabular}{|c|c|}
\hline \multicolumn{2}{|c|}{$\begin{array}{c}\text { Tabel 1. Pedoman Uji Autokorelasi Dengan Memakai Uji } \\
\text { Durbin-Watson (DW test) }\end{array}$} \\
\hline$<1,000$ & Ada autokorelasi \\
\hline $1,100-1,540$ & Tanpa kesimpulan \\
\hline $1,550-2,460$ & Tidak ada autokorelasi \\
\hline $2,460-2,900$ & Tanpa kesimpulan \\
\hline$>2,900$ & Ada autokorelasi \\
\hline & Sumber : Algifari, (2011:88). \\
\hline
\end{tabular}

\section{d. Uji Heteroskesdastisitas}

Menurut Ghozali (2013) "Uji heteroskedastisitas bertujuan untuk mengetahui apakah dalam model regresi terjadi ketidaksamaan varian dari suatu residual pengamatan ke pengamatan lain". Untuk mengetahui ada tidaknya heteroskedastisitas adalah dengan menggunakan uji scatter plot dengan melihat grafik antara nilai prediksi variabel terikat (ZPRED) dan nilai residualnya (SRESID) dengan ketentuan sebagai berikut :

1) Jika penyebaran titik-titik pada data scatter plot membentuk pola tertentu yang teratur seperti gelombang besar melebar, kemudian menyempit, atau dengan baik turun mengelompok menjadi satu, maka telah terjadi heteroskedastisitas.

2) Jika titik-titik menyebar diatas dan dibawah angka 0 pada sumbu $Y$ tanpa membentuk pola tertentu, maka tidak terjadi problem heteroskedastisitas.

\section{Analisis Deskriptif dan Verifikatif a. Analisis Deskriptif}

Analisis dilakukan dengan menyajikan data, menganalisis melalui perhitungan, penjelasan perkembangan setiap variabel dan pengolahan data dengan statistik guna menguji hipotesis.

\section{b. Analisis Verivikatif}

Analisis kuatitatif adalah penelitian yang telah dilakukan untuk menilai kondisi dari nilai 
pengaruh, signifikansi pengaruh, dan kelayakan model. Menurut Sugiyono (2014) "Metode verifikatif merupakan penelitian yang bertujuan untuk mengetahui hubungan antara 2 (dua) variabel atau lebih. Dengan demikian dari hasil dari analisis ini akan memberikan jawaban awal dari kalimat tanya pada perumusan masalah : bagaimana pengaruh variabel independen terhadap variabel dependen secara parsial maupun secara simultan. Adapun tahapan analisis yang dilakukan meliputi:

1) Analisis Regresi Lnier Sederhana

Analisis regresi liner sederhana ini dalam penelitian ini dimaksudkan untuk menganalisis pengaruh secara parsial antara variabel Capital Adequacy Ratio (CAR) dan Non Performing Loan (NPL) Terhadap Return On Assets (ROA) pada Bank BUMN.

2) Analisis Regresi Berganda

Di mana untuk mencapai tujuan penelitian yaitu menganalisis pengaruh Capital Adequacy Ratio (CAR) dan Non Performing Loan (NPL) Terhadap Return On Assets (ROA) pada Bank BUMN yaitu dengan menggunakan analisis regresi berganda (Multiple regresional analisis).

3) Analisis Koefisien Korelasi

Analisis ini bertujuan untuk mengetahui tingkat keterhubungan atau pengaruh masing-masing variabel independen terhadap variabel dependennya baik secara parsial maupun secara simultan.

4) Analisis Koefisien Determinasi Dalam penelitian ini untuk mengetahui berapa besar prosentase kontribusi dari variabel Return On Assets (ROA) pada Bank BUMN, baik secara parsial maupun secara simultan.

5) Pengujian Hipotesis

Pengujian hipotesis dimaksudkan untuk menguji dugaan sementara yang dirumuskan dalam hipotesis berdasarkan data empiris. Dalam penelitian ini pengujian hipotesis dilakukan dengan uji t dan uji F.

(a) Uji t (Parsial)

Uji t digunakan untuk menguji signifikansi variasi hubungan antar variabel $\mathrm{X}$ dan $\mathrm{Y}$, apakah variabel $\mathrm{X}_{1}$ dan $\mathrm{X}_{2}$ benar-benar berpengaruh secara parsial terhadap variabel dependen.(Y).

(b) Uji F (Simultan)

Pengujian hipotesis simultan (Uji F) bertujuan untuk mengetahui pengaruh secara bersama-sama antara variabel variabel independen $\left(\mathrm{X}_{1}\right.$ dan $\left.\mathrm{X}_{2}\right)$ terhadap variabel dependen $(\mathrm{Y})$.

\section{HASIL PENELITIAN DAN PEMBAHASAN Hasil Penelitian \\ Analisis Deskriptif Variabel Penelitian}

Sesuai dengan tujuan analisis deskriptif yaitu untuk memberikan gambaran mengenai hasil penelitian secara umum, bagaimana karakteristik subyek penelitian sehubungan dengan variabel-variabel yang diteliti. Sebelum dilakukan analisis statistik terlebih dahulu dilakukan pengelompokan data dan menghitung presentase setiap tahunnya yang disajikan sebagai berikut:

\begin{tabular}{|c|c|c|c|c|c|c|c|c|c|c|}
\hline \multirow{2}{*}{ Bank } & \multicolumn{10}{|c|}{ Nilai CAR Tahun } \\
\hline & 2006 & 2007 & 2008 & 2009 & 2010 & 2011 & 2012 & 2013 & 2014 & 2015 \\
\hline Bank Mandiri (Persero) & 25.3 & 21.11 & 15.72 & 15.6 & 14.14 & 15.34 & 15.48 & 14.93 & 19.2 & 18.6 \\
\hline PT Bank Rakyat Indonesia & 18.82 & 15.84 & 13.18 & 13.2 & 13.76 & 14.96 & 16.95 & 16.99 & 18.57 & 20.59 \\
\hline PT Bank Negara Indonesia & 15.3 & 15.74 & 13.59 & 13.78 & 18.63 & 17.63 & 16.67 & 15.09 & 16.22 & 19.49 \\
\hline PT Bank Tabungan Negara & 18.23 & 21.86 & 16.14 & 21.54 & 16.74 & 15.03 & 17.69 & 15.62 & 14.64 & 16.97 \\
\hline
\end{tabular}

Berdasarkan tabel diatas menunjukan bahwa rasio CAR tertinggi tahun 2006 diperoleh bank Mandiri dengan 25,3\% dan terendah BNI sebesar 15,3\%. Rasio CAR tertinggi tahun 2007 diperoleh BTN dengan $21,86 \%$ dan terendah
BNI sebesar 15,74\%. Rasio CAR tertinggi tahun 2008 diperoleh BTN dengan 16,4\% dan terendah BRI sebesar 13,18\%. Rasio CAR tertinggi tahun 2009 diperoleh BTN dengan $21,54 \%$ dan terendah BRI sebesar 13,2\%. Rasio 
CAR tertinggi tahun 2010 diperoleh BNI dengan $18,63 \%$ dan terendah BRI sebesar 13,76\%. Rasio CAR tertinggi tahun 2011 diperoleh BNI dengan 17,63\% dan terendah BRI sebesar 14,96\%. Rasio CAR tertinggi tahun 2012 diperoleh BTN dengan 17,69\% dan terendah Mandiri sebesar 15,48\%. Rasio CAR tertinggi tahun 2013 diperoleh BRI dengan 16,99\% dan terendah Mandiri sebesar 14,93\%. Rasio CAR tertinggi tahun 2014 diperoleh Mandiri dengan 19,2\% dan terendah BTN sebesar 14,64\%. Rasio CAR tertinggi tahun 2015 diperoleh BRI dengan 20,59\% dan terendah BTN sebesar 16,97\%.

1. Variabel Non Performing Loan (NPL) $\left(\mathrm{X}_{2}\right)$ Berdasarkan data rasio antara kredit bermasalah terhadap kredit yang disalurkan untuk tahun 2006-2015, sebagai berikut :

\begin{tabular}{|c|c|c|c|c|c|c|c|c|c|c|}
\hline \multicolumn{11}{|c|}{ Tabel 3. Hasil Perhitungan NPL } \\
\hline \multirow{2}{*}{ Bank } & \multicolumn{10}{|c|}{ Nilai NPL Per Tahun } \\
\hline & 2006 & 2007 & 2008 & 2009 & 2010 & 2011 & 2012 & 2013 & 2014 & 2015 \\
\hline Bank Mandiri (Persero) & 5.9 & 1.32 & 0.97 & 0.54 & 0.69 & 0.45 & 0.37 & 0.43 & 0.45 & 2.29 \\
\hline PT Bank Rakyat Indonesia & 4.81 & 3.44 & 2.8 & 3.52 & 2.78 & 2.3 & 1.78 & 1.55 & 0.36 & 2.02 \\
\hline PT Bank Negara Indonesia & 6.55 & 4.01 & 4.9 & 0.84 & 1.11 & 0.51 & 0.75 & 0.55 & 0.39 & 2.7 \\
\hline PT Bank Tabungan Negara & 1.77 & 2.81 & 2.66 & 2.75 & 2.66 & 2.23 & 3.12 & 3.04 & 2.76 & 3.42 \\
\hline
\end{tabular}

Berdasarkan data di bawah, menunjukkan bahwa rasio NPL tertinggi tahun 2006 diperoleh bank BNI dengan 6,55\% dan terendah BTN sebesar 1,77\%. Rasio NPL tertinggi tahun 2007 diperoleh BNI dengan 4,01\% dan terendah Mandiri sebesar 1,32\%. Rasio NPL tertinggi tahun 2008 diperoleh BNI dengan 4,9\% dan terendah Mandiri sebesar 0,97\%. Rasio NPL tertinggi tahun 2009 diperoleh BRI dengan 3,52\% dan terendah Mandiri sebesar 0,54\%. Rasio NPL tertinggi tahun 2010 diperoleh BRI dengan 2,3\% dan terendah Mandiri sebesar $0,69 \%$. Rasio NPL tertinggi tahun 2011 diperoleh BRI dengan 2,3\% dan terendah Mandiri sebesar 0,37\%. Rasio NPL tertinggi tahun 2012 diperoleh BTN dengan 3,12\% dan terendah Mandiri sebesar 0,37\%. Rasio NPL tertinggi tahun 2013 diperoleh BTN dengan 3,04\% dan terendah Mandiri sebesar 0,43\%. Rasio NPL tertinggi tahun 2014 diperoleh Mandiri dengan $2,76 \%$ dan terendah BRI sebesar $0,36 \%$. Rasio NPL tertinggi tahun 2015 diperoleh BTN dengan 3,24\% dan terendah BRI sebesar 2,02\%.

\section{Variabel Return On Asset (ROA) (Y)}

Rasio ini menggambarkan kemampuan Bank dalam menghasilkan laba pada setiap tahunnya. Adapun data yang diperoleh sebagai berikut:

\begin{tabular}{|c|c|c|c|c|c|c|c|c|c|c|}
\hline \multirow{2}{*}{ Bank } & \multicolumn{10}{|c|}{ Nilai ROA Per Tahun } \\
\hline & 2006 & 2007 & 2008 & 2009 & 2010 & 2011 & 2012 & 2013 & 2014 & 2015 \\
\hline Bank Mandiri (Persero) & 1.1 & 2.4 & 2.69 & 2.87 & 3.06 & 3.37 & 2.52 & 2.57 & 2.42 & 3.15 \\
\hline PT Bank Rakyat Indonesia & 4.36 & 4.61 & 4.18 & 3.73 & 4.64 & 4.93 & 5.15 & 3.41 & 3.02 & 3.95 \\
\hline PT Bank Negara Indonesia & 1.85 & 0.85 & 1.1 & 1.72 & 2.49 & 2.94 & 2.92 & 3.36 & 3.49 & 3.6 \\
\hline PT Bank Tabungan Negara & 1.78 & 1.89 & 1.8 & 1.47 & 2.05 & 2.03 & 1.94 & 1.79 & 1.14 & 1.61 \\
\hline
\end{tabular}

Berdasarkan datatabeldiatas, menunjukkan bahwa rasio ROA tertinggi tahun 2006 diperoleh bank BRI dengan 4,36\% dan terendah Mandiri sebesar 1,1\%. Rasio ROA tertinggi tahun 2007 diperoleh BRI dengan 4,61\% dan terendah BNI sebesar $0,85 \%$. Rasio ROA tertinggi tahun 2008 diperoleh BRI dengan 4,18\% dan terendah BNI sebesar 1,1\%. Rasio ROA tertinggi tahun 2009 diperoleh BRI dengan 3,73\% dan terendah BTN sebesar 1,47\%. Rasio ROA tertinggi tahun 2010 diperoleh BTN dengan 4,64\% dan terendah BTN sebesar 2,05\%. Rasio ROA tertinggi tahun 2011 diperoleh BRI dengan 4,93\% dan terendah BTN sebesar 2,03\%. Rasio ROA tertinggi tahun 
2012 diperoleh BRI dengan 5,15\% dan terendah BTN sebesar 1,94\%. Rasio ROA tertinggi tahun 2013 diperoleh BRI dengan 3,41\% dan terendah BTN sebesar 1,79\%. Rasio ROA tertinggi tahun 2014 diperoleh BNI dengan 3,49\% dan terendah BTN sebesar 1,14\%. Rasio ROA tertinggi tahun 2015 diperoleh BRI dengan 3,95\% dan terendah BTN sebesar 1,61\%.

\section{Pengujian Asumsi Klasik}

\section{Uji Normalitas}

Uji normalitas dilakukan untuk menguji apakah dalam model regresi, variabel dependen dan variabel independen berdistribusi normal atau berdistribusi tidak normal. Berikut ini Hasil uji normalitas dengan alat uji KolmogorovSmirnov Test, sebagai berikut:

\begin{tabular}{|c|r|r|r|r|r|r|}
\hline Tabel 5. Hasil Normalitas Dengan Kolmogorov-Smirnov Test \\
\hline & \multicolumn{2}{|c|}{$\begin{array}{c}\text { Kolmogorov- } \\
\text { Smirnov }\end{array}$} & \multicolumn{3}{|c|}{ Shapiro-Wilk } \\
\cline { 2 - 7 } & Statistic & \multicolumn{1}{c|}{ Df } & Sig. & Statistic & df & Sig. \\
\hline ROA (Y) & .068 & 40 & $.200^{*}$ & .979 & 40 & .640 \\
\hline \multicolumn{6}{|c|}{ Sumber : Data primer diolah. } \\
\hline
\end{tabular}

Berdasarkan hasil pengujian pada tabel di atas, diperoleh nilai signifikansi $\alpha=0,200 \mathrm{di}$ mana nilai tersebut lebih besar dari $\alpha=0,050$ atau $(0,200>0,05)$. Dengan demikian maka memenuhi unsur normalitas.

\section{Uji Multikonilieritas}

Pengujian mutlikolinearitas dilakukan untuk meyakini bahwa antar variabel bebas tidak memiliki multikolinearitas atau tidak memiliki hubungan korelasi antara variabel yang ditetapkan sebagai model dalam penelitian, karena model regresi yang baik seharusnya tidak terjadi korelasi di antara variabel independen. Uji multikolinearitas dilakukan dengan melihat nilai Tolerance Value dan Variance Inflation Factor (VIF). Adapun hasil pengujiannya sebagai berikut:

\begin{tabular}{|l|c|c|}
\hline \multirow{2}{*}{ Tabel 6. Hasil Uji Multikolinieritas Dengan Collinierity Statistic } \\
\cline { 2 - 3 } & \multicolumn{2}{|c|}{ Collinearity Statistics } \\
\hline 1 (Constant) & Tolerance & VIF \\
\hline CAR $\left(X_{1}\right)$ & .979 & 1.022 \\
\hline NPL $\left(X_{2}\right)$ & .979 & 1.022 \\
\hline \multicolumn{2}{|c|}{ Sumber: Data diolah } \\
\hline
\end{tabular}

Berdasarkan hasil pengujian pada tabel di atas, nilai tolerance masing-masing variabel bebas $<$ 1,0 dan nilai Variance Inflation Factor (VIF) sebesar $<10$, dengan demikian model regresi ini tidak ada multikolinearitas.

\section{Uji Autokorelasi}

Pengujian Autokorelasi digunakan untuk mengetahui ada atau tidaknya penyimpangan korelasi antar anggota sampel. Pengujian dilakukan dengan alat uji Darbin-Watson (DW test). Adapun hasil pengujiannya sebagai berikut:

\begin{tabular}{|l|r|r|r|r|r|}
\hline \multicolumn{7}{|c|}{ Tabel 7. Hasil Uji Autokorelasi } \\
\hline Model Summaryb \\
\hline 1 & R & R Square & $\begin{array}{c}\text { Adjusted R } \\
\text { Square }\end{array}$ & $\begin{array}{c}\text { Std. Error of } \\
\text { the Estimate }\end{array}$ & $\begin{array}{r}\text { Durbin- } \\
\text { Watson }\end{array}$ \\
\hline \multicolumn{7}{|c|}{} & $.328^{\mathrm{a}}$ & .107 & .059 & 128.836 & 2.234 \\
\hline
\end{tabular}

Berdasarkan hasil pengujian pada tabel di atas, model regresi ini tidak ada autokorelasi, hal ini dibuktikan dengan nilai Durbin-Watson sebesar 2.234 yang berada diantara interval $1.550-2.460$.

\section{Uji Heteroskesdastisitas}

Pengujian heteroskedastisitas dimaksudkan untuk menguji apakah dalam sebuah model regresi terjadi ketidaksamaan varians residual. Salah satu cara untuk mendeteksi ada tidaknya heteroskedastisitas adalah dengan uji scater plot. Adapun hasil nya sebagai berikut:

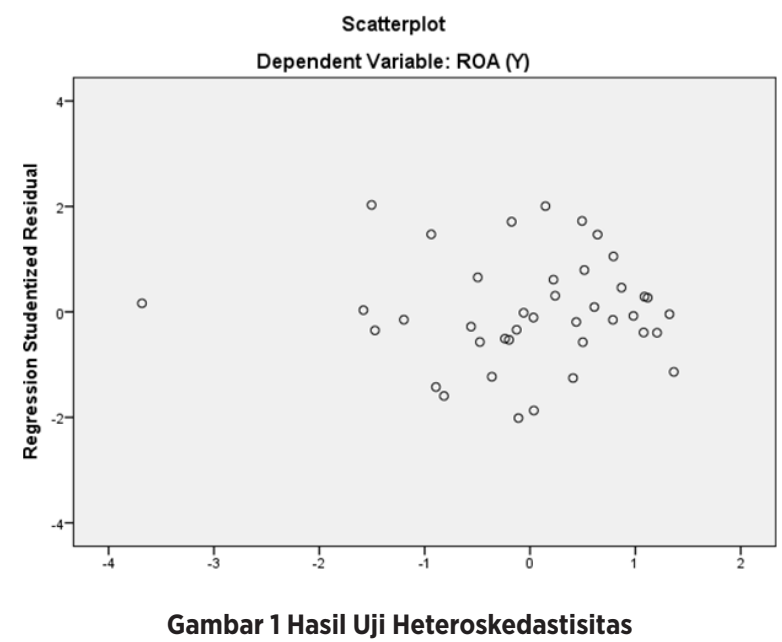

Berdasarkan gambar di atas, disimpulkan tidak terdapat gangguan heteroskedastisitas, hal ini dibuktikan dengan titik-titik pada grafik scatterplot tidak mempunyai pola penyebaran yang jelas dan titik-titik tersebut menyebar di atas dan dibawah angka 0 (nol) pada sumbu Y. 


\section{Hasil Analisis Data}

Pada bagian pengujian ini dimaksudkan untuk menunjukkan hasil dari pengujian atas variabel CAR $\left(\mathrm{X}_{1}\right)$ dan NPL $\left(\mathrm{X}_{2}\right)$ Terhadap ROA $(\mathrm{Y})$. Adapun hasil analisis dalam penelitian ini sebagai berikut:

\section{Analisis Regresi Linier Sederhana}

Uji regresi linier sederhana ini dimaksudkan untuk mengetahui seberapa besar pengaruh variabel CAR $\left(\mathrm{X}_{1}\right)$ dan NPL $\left(\mathrm{X}_{2}\right)$ terhadap ROA (Y) secara sendiri-sendiri. Adapun hasil analisis regresi linier sederhana sebagai berikut Berdasarkan perhitungan regresi berganda diperoleh hasil sebagai berikut :

\begin{tabular}{|c|c|c|c|c|c|}
\hline \multicolumn{6}{|c|}{$\begin{array}{l}\text { Tabel 8. Hasil Uji Regresi Linier Sederhana } \\
\text { Antara CAR }\left(X_{1}\right) \text { Terhadap ROA (Y) }\end{array}$} \\
\hline \multicolumn{6}{|c|}{ Coefficients $^{\mathrm{a}}$} \\
\hline \multirow[b]{2}{*}{ Model } & \multicolumn{2}{|c|}{$\begin{array}{l}\text { Unstandardized } \\
\text { Coefficients }\end{array}$} & \multicolumn{3}{|c|}{ Standardized Coefficients } \\
\hline & B & Std. Error & Beta & $t$ & Sig. \\
\hline 1 (Constant) & 478.348 & 133.934 & & 3.572 & .00 \\
\hline $\operatorname{CAR}\left(X_{1}\right)$ & -13.294 & 7.833 & -265 & -1.697 & .098 \\
\hline
\end{tabular}

Dari hasil perhitungan pada tabel di atas dapat disajikan ke dalam bentuk persamaan regresi standardized: $\mathrm{Y}=\mathbf{4 7 8 , 3 4 8}-\mathbf{1 3}, \mathbf{2 9 4} \mathrm{X}_{1}$

Adapun persamaan tersebut dapat dijelaskan sebagai berikut :

a. Konstanta sebesar 478,348, menyatakan bahwa tanpa dipengaruhi variabel CAR maka besarnya nilai rentabilitas sudah terbentuk sebesar 478,348.

b. Variabel CAR $\left(\mathrm{X}_{1}\right)$ berpengaruh negatif terhadap RAO (Y) dengan nilai koefisien sebesar -13,294, yang artinya jika variabel CAR (X1) meningkat satu satuan dengan asumsi variabel lain tetap, maka ROA akan mengalami penurunan sebesar -13,294 satuan.

\begin{tabular}{|c|c|c|c|c|c|}
\hline \multicolumn{6}{|c|}{$\begin{array}{l}\text { Tabel 9. Hasil Uji Regresi Linier Sederhana } \\
\text { Antara NPL }\left(\mathrm{X}_{2}\right) \text { Terhadap ROA }(\mathrm{Y})\end{array}$} \\
\hline \multicolumn{6}{|c|}{ Coefficients $^{a}$} \\
\hline \multirow[b]{2}{*}{ Model } & \multicolumn{2}{|c|}{$\begin{array}{l}\text { Unstandardized } \\
\text { Coefficients }\end{array}$} & \multicolumn{3}{|c|}{ Standardized Coefficients } \\
\hline & B & Std. Error & Beta & $t$ & Sig. \\
\hline 1 (Constant) & 296.274 & 35.954 & & 8.240 & .000 \\
\hline $\operatorname{NPL}\left(X_{2}\right)$ & -19.275 & 13.313 & -229 & -1.448 & .156 \\
\hline
\end{tabular}

Dari hasil perhitungan pada tabel di atas dapat disajikan ke dalam bentuk persamaan regresi standardized: $\mathrm{Y}=\mathbf{2 9 6}, \mathbf{2 7 4}-\mathbf{1 9 , 2 7 5 \mathrm { X } _ { 2 }}$
Adapun persamaan tersebut dapat dijelaskan sebagai berikut :

a. Konstanta sebesar 296,274, menyatakan bahwa tanpa dipengaruhi variabel NPL, maka besarnya nilai ROA sudah terbentuk sebesar 296,274.

b. Variabel NPL $\left(\mathrm{X}_{2}\right)$ berpengaruh negatif terhadap ROA (Y) dengan nilai koefisien sebesar $-19,275$. Yang artinya jika variabel NPL $\left(\mathrm{X}_{2}\right)$ meningkat satu satuan dengan asumsi variabel lain tetap, maka ROA akan mengalami penurunan sebesar $-19,275$ satuan.

\section{Analisis Regresi Berganda}

Analisis regresi berganda dimaksudkan untuk mengetahui seberapa besar pengaruh variabel CAR $\left(\mathrm{X}_{1}\right)$ dan NPL $\left(\mathrm{X}_{2}\right)$ terhadap ROA (Y). Berdasarkan perhitungan regresi berganda diperoleh hasil sebagai berikut :

\begin{tabular}{|l|r|r|r|r|r|}
\hline \multicolumn{5}{|c|}{ Coefficients $^{\mathbf{a}}$} \\
\hline \multirow{3}{*}{ Model } & \multicolumn{1}{|c|}{$\begin{array}{c}\text { Unstandardized } \\
\text { Coefficients }\end{array}$} & \multicolumn{3}{|c|}{ Standardized Coefficients } \\
\cline { 2 - 6 } & \multicolumn{1}{|c|}{ B } & Std. Error & \multicolumn{1}{|c|}{ Beta } & \multicolumn{1}{c|}{$\mathbf{t}$} & \multicolumn{1}{c|}{ Sig. } \\
\hline 1 (Constant) & 490.631 & 133.379 & & 3.678 & .001 \\
\hline CAR $\left(X_{1}\right)$ & -11.882 & 7.862 & -.237 & -1.511 & .139 \\
\hline NPL $\left(X_{2}\right)$ & -16.372 & 13.234 & -194 & -1.237 & .224 \\
\hline & \multicolumn{5}{|c|}{ Sumber : Data primer diolah } \\
\hline
\end{tabular}

Berdasarkan hasil perhitungan pada tabel di atas dapat disajikan ke dalam bentuk persamaan regresi standardized sebagai berikut : $\mathbf{Y}$ $=490,631-11,882 \mathrm{X}_{1}-16,372 \mathrm{X}_{2}$

Adapun persamaan tersebut dapat dijelaskan sebagai berikut:

a. Nilai konstanta diperoleh sebesar 490,631, menyatakan bahwa tanpa dipengaruhi oleh variabel CAR $\left(\mathrm{X}_{1}\right)$ dan NPL $\left(\mathrm{X}_{2}\right)$ besarnya nilai ROA (Y) sudah terbentuk sebesar 490,631.

b. Variabel CAR (X1) berpengaruh negatif dan tidak signifikan terhadap ROA (Y) dengan nilai koefisien sebesar -11,882. Hal ini diartikan bahwa jika variabel CAR $\left(\mathrm{X}_{1}\right)$ meningkat satu satuan dengan asumsi variabel NPL $\left(\mathrm{X}_{2}\right)$ tetap atau konstan $(0)$, maka ROA (Y) akan mengalami penurunan $-11,882$.

c. Variabel NPL(X2) berpengaruh negatif dan tidak signifikan terhadap ROA (Y) dengan nilai koefisien sebesar -16,372. 
Hal ini diartikan bahwa jika variabel NPL $\left(\mathrm{X}_{2}\right)$ meningkat satu satuan dengan asumsi variabel CAR $\left(\mathrm{X}_{1}\right)$ tetap atau konstan $(0)$, maka ROA (Y) akan mengalami penurunan sebesar $-16,372$.

\section{Analisis Koefisien Korelasi}

Analisis koefisien korelasi (R) digunakan untuk mengetahui tingkat kekuatan hubungan atau pengaruh dari variabel bebas terhadap variabel terikat, dalam hal ini adalah variabel CAR $\left(X_{1}\right)$ dan NPL $\left(X_{2}\right)$ baik secara parsial maupun secara simultan terhadap ROA (Y). Adapun hasil pengolahan data dapat dijelaskan sebagai berikut :

\begin{tabular}{|c|c|c|c|}
\hline \multicolumn{4}{|c|}{$\begin{array}{l}\text { Tabel 11. Hasil Uji Koefisien Korelasi } \\
\text { Pengaruh CAR }\left(\mathrm{X}_{1}\right) \text { Terhadap ROA }(Y)\end{array}$} \\
\hline \multicolumn{4}{|c|}{ Coefficients $^{\mathrm{a}}$} \\
\hline & & $\operatorname{CAR}\left(X_{1}\right)$ & ROA (Y) \\
\hline \multirow{2}{*}{$\operatorname{CAR}\left(X_{1}\right)$} & Correlation & 1 & -.265 \\
\hline & Sig. (2-tailed) & & .098 \\
\hline \multirow{2}{*}{$\mathrm{ROA}(\mathrm{Y})$} & Correlation & -.265 & 1 \\
\hline & Sig. (2-tailed) & .098 & \\
\hline
\end{tabular}

Berdasarkan hasil pada tabel di atas diperoleh nilai korelasi sebesar -0,265. Hal ini menunjukkan bahwa variabel $\operatorname{CAR}\left(\mathrm{X}_{1}\right)$ secara parsial memiliki tingkat hubungan yang lemah namun negatif terhadap ROA (Y).

\begin{tabular}{|c|c|c|c|}
\hline \multicolumn{4}{|c|}{$\begin{array}{l}\text { Tabel 12. Hasil Uji Koefisien Korelasi } \\
\text { Pengaruh NPL }\left(\mathrm{X}_{2}\right) \text { Terhadap ROA }(\mathrm{Y})\end{array}$} \\
\hline \multicolumn{4}{|c|}{ Coefficients $^{a}$} \\
\hline & & $\operatorname{CAR}\left(X_{1}\right)$ & ROA (Y) \\
\hline \multirow{2}{*}{$\operatorname{NPL}\left(X_{2}\right)$} & Correlation & 1 & -.229 \\
\hline & Sig. (2-tailed) & & .156 \\
\hline \multirow{2}{*}{$\mathrm{ROA}(\mathrm{Y})$} & Correlation & -229 & 1 \\
\hline & Sig. (2-tailed) & .156 & \\
\hline \multicolumn{4}{|c|}{ Sumber : Data primer diolah } \\
\hline
\end{tabular}

Berdasarkan hasil pada tabel di atas diperoleh nilai korelasi sebesar -0,229 Hal ini menunjukkan bahwa variabel NPL $\left(\mathrm{X}_{2}\right)$ secara parsial memiliki tingkat hubungan yang lemah namun negatif terhadap ROA (Y).

\begin{tabular}{|c|c|c|c|c|}
\hline \multicolumn{5}{|c|}{$\begin{array}{l}\text { Tabel 15. Hasil Uji Koefisien Korelasi Pengaruh CAR }\left(X_{1}\right) \text { dan } \\
\text { NPL }\left(X_{2}\right) \text { secara simultan Terhadap ROA }(Y)\end{array}$} \\
\hline \multicolumn{5}{|c|}{ Model Summary } \\
\hline Model & $\mathbf{R}$ & R Square & Adjusted R Square & $\begin{array}{l}\text { Std. Error of } \\
\text { the Estimate }\end{array}$ \\
\hline 1 & $.328^{\mathrm{a}}$ & .107 & .059 & 128.836 \\
\hline
\end{tabular}

Berdasarkan hasil pada tabel di atas diperoleh nilai korelasi sebesar 0,328. Hal ini menunjukkan bahwa variabel $\mathrm{CAR}\left(\mathrm{X}_{1}\right)$ dan NPL $\left(\mathrm{X}_{2}\right)$ secara simultan memiliki tingkat hubungan yang lemah terhadap ROA (Y).

\section{Analisis Koefisien Determinasi}

Analisis koefisien deteminasi digunakan untuk mengetahui kontribusi besarnya pengaruh antara variabel bebas terhadap variabel terikat, dalam hal ini adalah variabel CAR $\left(\mathrm{X}_{1}\right)$ dan NPL $\left(\mathrm{X}_{2}\right)$ baik secara parsial maupun secara simultan terhadap ROA (Y). Adapun hasil pengolahan data dapat dijelaskan sebagai berikut:

\begin{tabular}{|c|r|r|r|r|}
\hline \multicolumn{5}{|c|}{$\begin{array}{c}\text { Tabel 13. Hasil Uji Koefisien Determinasi } \\
\text { Pengaruh CAR }\left(\mathbf{X}_{1}\right) \text { Terhadap ROA }(\mathrm{Y})\end{array}$} \\
\hline Model & \multicolumn{1}{|c|}{$\mathbf{R}$} & \multicolumn{1}{c|}{ R Square } & Adjusted R Square & $\begin{array}{r}\text { Std. Error of } \\
\text { the Estimate }\end{array}$ \\
\hline 1 & $.265^{\mathrm{a}}$ & .070 & .046 & 129.732 \\
\hline \multicolumn{6}{|c|}{ Sumber : Data primer diolah } \\
\hline
\end{tabular}

Berdasarkan hasil pada tabel di atas dapat dilihat bahwa nilai $R$ Square sebesar 0,070 atau $7,0 \%$. Hal ini menunjukkan bahwa pengaruh CAR $\left(\mathrm{X}_{1}\right)$ secara parsial terhadap rentabilitas adalah sebesar 7,0\%.

\begin{tabular}{|l|r|r|r|r|}
\hline \multicolumn{5}{|c|}{$\begin{array}{c}\text { Tabel 14. Hasil Uji Determinasi } \\
\text { Pengaruh NPL }\left(\mathbf{X}_{2}\right) \text { Terhadap ROA }(\mathbf{Y})\end{array}$} \\
\hline Model & \multicolumn{1}{|c|}{$\mathbf{R}$} & \multicolumn{1}{|c|}{ R Square } & Adjusted R Square & $\begin{array}{r}\text { Std. Error of } \\
\text { the Estimate }\end{array}$ \\
\hline 1 & $.229^{\mathrm{a}}$ & .052 & .027 & 130.994 \\
\hline \multicolumn{6}{|c|}{ Sumber : Data primer diolah } \\
\hline
\end{tabular}

Berdasarkan hasil pada tabel di atas dapat dilihat bahwa nilai $R$ Square sebesar 0,052 atau $5,2 \%$. Hal ini menunjukkan bahwa pengaruh NPL $\left(\mathrm{X}_{2}\right)$ secara parsial terhadap ROA (Y) adalah sebesar $5,2 \%$.

\begin{tabular}{|c|r|r|r|r|}
\hline \multicolumn{6}{|c|}{ Tabel 15. Hasil Uji Koefisien Determinasi } \\
Pengaruh CAR $\left(X_{1}\right)$ dan NPL $\left(X_{2}\right)$ Terhadap ROA $(Y)$
\end{tabular}

Berdasarkan hasil pada tabel di atas dapat dilihat bahwa nilai $R$ Square sebesar 0,107 atau $10,7 \%$. Hal ini menunjukkan bahwa pengaruh 
CAR $\left(\mathrm{X}_{1}\right)$ dan NPL $\left(\mathrm{X}_{2}\right)$ secara simultan terhadap ROA (Y) adalah sebesar 10,7\%.

\section{Pengujian Hipotesis}

Pengujian hipotesis dimaksudkan untuk menetukan apakah sebaiknya hipotesis diterima atau ditolak. Dalam pengujian ini digunakan uji $\mathrm{t}$ (parsial) dan uji F (Simultan).

\section{a. Uji Hipotesis Parsial (Uji t)}

Pengujian hipotesis secara parsial menggunakan uji t yaitu untuk menguji bagaimana pengaruh masing-masing variabel bebas secara sendiri-sendiri terhadap variabel terikatnya.

Hipotesis Pertama : Terdapat pengaruh signifikan antara CAR terhadap ROA.

\begin{tabular}{|c|c|c|c|c|c|}
\hline \multicolumn{6}{|c|}{$\begin{array}{r}\text { Tabel 16. Pengujian Hipotesis Va } \\
\text { Terhadap ROA (Y }\end{array}$} \\
\hline \multicolumn{6}{|c|}{ Coefficients ${ }^{a}$} \\
\hline \multirow[b]{2}{*}{ Model } & \multicolumn{2}{|c|}{$\begin{array}{l}\text { Unstandardized } \\
\text { Coefficients }\end{array}$} & \multicolumn{3}{|c|}{ Standardized Coefficients } \\
\hline & B & Std. Error & Beta & $\mathbf{t}$ & Sig. \\
\hline 1 (Constant) & 478.348 & 133.934 & & 3.572 & .001 \\
\hline $\operatorname{CAR}\left(X_{1}\right)$ & -13.294 & 7.833 & -.265 & -1.697 & .098 \\
\hline \multicolumn{6}{|c|}{ Sumber : Data primer diolah } \\
\hline
\end{tabular}

Berdasarkan hasil pengolahan data di atas, diperoleh nilai $\mathrm{t}_{\text {hitung }}<\mathrm{t}_{\text {tabel }}$ atau $(-1,697<1,943)$, hal itu juga diperkuat dengan signifikansi 0,098 $>0,05$. Dengan demikian hipotesis pertama yang menyatakan terdapat pengaruh signifikan antara CAR terhadap ROA ditolak.

Hipotesis Kedua : Terdapat pengaruh signifikan antara NPL terhadap ROA.

\begin{tabular}{|c|c|c|c|c|c|}
\hline \multicolumn{6}{|c|}{$\begin{array}{l}\text { Tabel 17. Pengujian Hipotesis Variabel NPL }\left(X_{2}\right) \\
\text { Terhadap ROA }(Y)\end{array}$} \\
\hline \multicolumn{6}{|c|}{ Coefficients $^{a}$} \\
\hline \multirow[b]{2}{*}{ Model } & \multicolumn{2}{|c|}{$\begin{array}{l}\text { Unstandardized } \\
\text { Coefficients }\end{array}$} & \multicolumn{3}{|c|}{ Standardized Coefficients } \\
\hline & B & Std. Error & Beta & $t$ & Sig. \\
\hline 1 (Constant) & 296.274 & 35.954 & & 8.240 & .000 \\
\hline $\mathrm{NPL}\left(\mathrm{X}_{2}\right)$ & -19.275 & 13.313 & -.229 & -1.448 & .156 \\
\hline
\end{tabular}

Berdasarkan hasil pengolahan data di atas, diperoleh nilai $\mathrm{t}_{\text {hitung }}<\mathrm{t}_{\text {tabel }}$ atau $(-1,448<1,943)$, hal itu juga diperkuat dengan signifikansi 0,156 $>0,05$. Dengan demikian hipotesis kedua yang menyatakan terdapat pengaruh signifikan antara NPL terhadap ROA ditolak.

\section{b. Uji Hipotesis Secara Simultan (Uji F)}

Pengujian hipotesis secara simultan (uji F) dimaksudkan untuk mengetahui pengaruh semua variabel bebas terhadap variabel terikat yaitu CAR dan NPL terhadap ROA.

Hipotesis Ketiga: Terdapat pengaruh signifikan antara CAR $\left(\mathrm{X}_{1}\right)$ dan $\mathrm{NPL}\left(\mathrm{X}_{2}\right)$ secara simultan terhadap RA (Y).

Adapun hasil pengujiannya sebagai berikut:

\begin{tabular}{l|l|r|r|c|c|c|}
\hline \multicolumn{7}{|c|}{ Tabel 18. Pengujian Hipotesis Secara Simultan } \\
\hline \multicolumn{7}{|c|}{ ANOVA $^{\mathrm{a}}$} \\
\hline \multirow{2}{*}{ Model } & \multicolumn{1}{c|}{$\begin{array}{c}\text { Sum of } \\
\text { Squares }\end{array}$} & df & $\begin{array}{c}\text { Mean } \\
\text { Square }\end{array}$ & F & Sig. \\
\hline \multirow{2}{*}{1} & Regression & 73877.732 & 2 & 36938.866 & 2.225 & $.122^{\mathrm{b}}$ \\
\cline { 2 - 8 } & Residual & 614150.243 & 37 & 16598.655 & & \\
\cline { 2 - 8 } & Total & 688027.975 & 39 & & & \\
\hline \multicolumn{7}{|c|}{ Sumber : Data primer diolah } \\
\hline
\end{tabular}

Berdasarkan hasil pengolahan data di atas, diperoleh nilai $\mathrm{F}_{\text {hitung }}<\mathrm{F}_{\text {tabel }}$ atau $(2,225<4,760)$, hal itu juga diperkuat dengan nilai signifikansi $0,122>0,05$. Dengan demikian hipotesis ketiga yang menyatakan terdapat pengaruh signifikan antara CAR dan NPL secara simultan terhadap ROA di tolak.

\section{Pembahasan}

Dari hasil pengujian statistik dan analisis diatas, maka dapat dipaparkan analisis pengaruh Capital Adequacy Ratio (CAR) dan Non Performing Loan (NPL) terhadap Return On Asset (ROA) pada Bank BUMN, sebagai berikut:

\section{Pengaruh Capital Adequacy Ratio (CAR)} terhadap Return On Asset (ROA)

Dari hasil analisis statistik, diperoleh persamaan regresi adalah $\mathrm{Y}=\mathbf{4 7 8 , 3 4 8}-\mathbf{1 3}, \mathbf{2 9 4} \mathrm{X}_{1}$. Koefisien beta memiliki nilai negatif sehingga CAR memiliki pengaruh yang negatif. Koefisien korelasi antara CAR terhadap ROA adalah sebesar -265. Dengan demikian dapat dikatakan bahwa kedua variabel memiliki hubungan yang negatif sebesar - 0,265 dengan tingkat hubungan atau pengaruh yang lemah. Nilai koefisien determinasi diperoleh sebesar 0,070 , data tersebut mengindikasikan bahwa variabel CAR memberikan kontribusi pengaruh sebesar 7,0\% terhadap ROA. Uji hipotesis diperoleh nilai $\mathrm{t}_{\text {hitung }}<\mathrm{t}_{\text {tabel }}$ atau $(-1,697<1,943)$ dan signifikansi $t>0,05$ atau $(0,984>0,05)$. Dengan demikian hipotesis $\mathrm{H}^{1}$ yang penulis ajukan ditolak, hal ini menunjukkan bahwa CAR berpengaruh negatif terhadap ROA. 


\section{Pengaruh Non Performing Loan (NPL) terhadap Return On Asset (ROA)}

Dari hasil analisis statistik, diperoleh persamaan model regresi adalah $\mathrm{Y}=\mathbf{2 9 6 , 2 7 4}$ - 19,275X. Konstanta memiliki nilai negatif sehingga NPL memiliki pengaruh yang negatif. Koefisien korelasi antara NPL terhadap ROA adalah sebesar -0,229. Dengan demikian dapat dikatakan bahwa kedua variabel memiliki hubungan yang negatif sebesar -0,229 dengan tingkat hubungan atau pengaruh yang lemah. Nilai koefisien determinasi diperoleh sebesar 0,052, data tersebut mengindikasikan bahwa variabel NPL memberikan kontribusi pengaruh sebesar 5,2\% terhadap ROA. Uji hipotesis diperoleh nilai $\mathrm{t}_{\text {hitung }}<\mathrm{t}_{\text {tabel }}$ atau $(-1,448<1,943)$ dan signifikansi $t<0,05$ atau $(0,156>0,05)$. Dengan demikian hipotesis $\mathrm{H}^{2}$ yang penulis ajukan ditolak, hal ini menunjukkan bahwa NPL berpengaruh negatif terhadap ROA.

\section{Pengaruh Capital Adequacy Ratio (CAR) dan Non Performing Loan (NPL) terhadap Return On Asset (ROA)}

Dari hasil analisis statistik, diperoleh persamaan model regresi adalah $\mathrm{Y}=\mathbf{4 9 0 , 6 3 1}$ - 11,882X $X_{1}-16,372 X_{2}$. Konstansta memiliki nilai positif sehingga apabila CAR dab NPL mengalami kenaikan, maka ROA juga akan meningkat. Koefisien korelasi antara CAR dan NPL secara simultan terhadap ROA adalah sebesar 0,328. Dengan demikian dapat dikatakan bahwa ketiga variabel memiliki hubungan sebesar 0,328 dengan tingkat hubungan atau pengaruh lemah. Nilai koefisien determinasi diperoleh sebesar 0,107, data tersebut mengindikasikan bahwa variabel CAR dan NPL secara simultan memberikan kontribusi pengaruh sebesar 10,7 terhadap ROA. Uji hipotesis diperoleh nilai $\mathrm{F}_{\text {hitung }}$ $<\mathrm{F}_{\text {tabel }}$ atau $(2,225<4,760)$, dan F signifikansi $>0,05$ atau $(0,122>0,05)$. Dengan demikian hipotesis $\mathrm{H} 3$ yang penulis ajukan ditolak, hal ini menunjukkan bahwa CAR dan NPL secara simultan berpengaruh negatif terhadap ROA.

\section{KESIMPULAN DAN SARAN Kesimpulan}

Setelah penulis melakukan penelitian dan analisis mengenai pengaruh Capital Adequacy Ratio (CAR) dan Non Performing Loan (NPL) terhadap Return On Asset (ROA), seperti yang telah dipaparkan pada bab-bab sebelumnya, maka penulis dapat menarik kesimpulan sebagai berikut:

1. Capital Adequacy Ratio (CAR) berpengaruh negatif terhadap Return On Asset (ROA). Hal ini dapat dilihat dari Nilai $\mathrm{t}_{\text {hitung }}<$ $\mathrm{t}_{\text {tabel }}(-1,697<1,943)$ dan signifikansi $\mathrm{t}>$ 0,05 atau $(0,984>0,05)$ CAR mempunyai korelasi negatif sebesar $-0,265$. Kontribusi pengaruh sebesar 0,070 atau 7,0\%. Model regresi liner sederhana diperoleh $\mathrm{Y}=$ 478,348 - 13,294X $\mathrm{X}_{1}$ yang diartikan apabila CAR mengalami peningkatan, maka ROA akan mengalami penurunan.

2. Non Performing Loan (NPL) berpengaruh negatif terhadap Return On Asset (ROA). Hal ini dapat dilihat dari Nilai $\mathrm{t}_{\text {hitung }}<\mathrm{t}_{\text {tabel }}$ atau $(-1,448<1,943)$ dan signifikansi $t<$ 0,05 atau $(0,156>0,05)$. NPL mempunyai korelasi negatif sebesar $-0,229$. Kontribusi pengaruh sebesar 0,052 atau 5,2\%. Model regresi liner sederhana diperoleh $\mathrm{Y}=$ 296,274 - 19,275X 2 yang diartikan apabila NPL mengalami peningkatan, maka ROA akan mengalami penurunan.

3. Capital Adequacy Ratio (CAR) dan Non Performing Loan (NPL) secara simultan berpengaruh negatif terhadap Return On Asset (ROA). Hal ini dapat dilihat dari Nilai $\mathrm{F}_{\text {hitung }}<\mathrm{F}_{\text {tabel }}$ atau $(2,225<4,760)$, dan F signifikansi $>0,05$ atau $(0,122>0,05)$. CAR dan NPL secara simultan mempunyai kontribusi pengaruh sebesar $10,7 \%$ terhadap ROA. Model regresi berganda diperoleh adalah $\mathrm{Y}=490,631-11,882 \mathrm{X}_{1}-$ $16,372 \mathrm{X}_{2}$. yang diartikan apabila CAR dan NPL mengalami peningkatan, maka ROA akan mengalami penurunan.

\section{Saran}

Berdasarkan kesimpulan dan keterbatasan penelitian yang telah dilakukan, maka peneliti memberikan saran baik untuk perusahaan dan penelitian selanjutnya sebagai berikut :

1. Saran penulis berdasarkan temuan hasil penelitian maka untuk meningkatkan pendapatan maka hendaknya bank BUMN dapat menjalankan fungsi intermediasi yaitu dengan menyalurkan dana yang dimiliki (kredit) dengan bunga kredit yang lebih rendah, serta melakukan inovasi baru untuk menarik minat masyarakat dalam 
penggunaan fasilitas dana kredit yang ditawarkan oleh bank.

2. Bank BUMN harus terus meningkatkan nilai aset sehingga dapat memanfaatkan semaksimal mungkin aset yang dimiliki agar memperoleh pendapatan yang besar serta menghasilkan laba yang tinggi. Sehingga memiliki nilai CAR dan ROA yang tinggi. Hal ini akan menjadi daya tarik dan pertimbangan bagi investor dan pemegang saham untuk menginvestasikan dananya.

3. Bank BUMN harus berusaha semaksimal mungkin agar tingkat NPL berada dibawah 5\%. Semakin tinggi NPL akan mengakibatkan kerugian terhadap bank.

4. Hasil penelitian ini dapat dijadikan sebagai bahan pertimbangan dalam pengambilan keputusan investasi tentang kesehatan bank BUMN serta dapat menjadi cerminan untuk dapat mengambil keputusan yang tepat di dalam mengelola suatu bank.

\section{DAFTAR PUSTAKA}

Agus Harjito, Martono. 2007. Manajemen Keuangan. Yogyakarta: Ekonosia

Agus Sartono. 2001. Manajemen Keuangan Teori dan Aplikasi. Yogyakarta: BPFE Yogyakarta

Agus Sartono. 2008. Manajemen Keuangan Teori dan Aplikasi. Edisi Keempat, Yogyakarta: BPFE Yogyakarta

Achmad, Kusno, 2003. Analisis Rasio-rasio keuangan sebagai indikator dalam memprediksi potensi kebangkrutan perbankan Indonesia, Jakarta: Media Ekonomi dan Bisnis

Baltagi. 2005. Econometric Analysis Of Panel Data, 3e. Shoutern Gate: John Willey and Son

Bambang Riyanto. 2011. Dasar-dasar Pembelanjaan Perusahaan. Edisi keempat, Yogyakarta: BPFE Yogyakarta

Brigham Vegene, Besley Scott. 2008. Essential Of Managerial Finance. USA: South Western

Dahlan, Siamat, 2000. Manajemen Lembaga Keuangan "Kebijakan Moneter dan Perbankan", Jakarta: Fakultas Ekonomi Universitas Indonesia

Darsono Prawironegoro. 2007. Akuntansi Manajemen. Edisi kedua, Jakarta: Mitra Wacana Media
Dendawijaya, Lukman. 2000. Manajemen Perbankan. cetakan pertama, Jakarta: Ghalia Indonesia

Dendawijaya, Lukman. 2001. Manajemen Perbankan. cetakan kedua, Jakarta: Ghalia Indonesia

Dendawijaya, Lukman. 2005. Manajemen Perbankan. cetakan kedua, Jakarta: Ghalia Indonesia

George R Terry. 2003. Prinsip-Prinsip Manajemen. Jakarta: PT Bumi Aksara

Gujarati, N Damodar, 2004. Basic Econometrics Fourth Edition. Mc Grawhill

Harahap, Sofyan Safri. 2009. Analisis Kritis atas Laporan Keuangan. Jakarta : PT. Raja Grafindo Persada.

Hasibuan, Malayu . 2003. Manajemen Sumber Daya Manusia, Edisi Revisi. Jakarta : PT Bumi Aksara.

Hasibuan, Malayu. 2007. Dasar-Dasar Perbankan. Jakarta : PT Bumi Aksara.

Hasibuan, Malayu . 2009. Manajemen: Dasar Pengertian dan Masalah. Edisi revisi, Jakarta : PT Bumi Aksara.

Hasibuan, Malayu . 2012. Manajemen sumber daya manusia. Cetakan 16, Jakarta : PT Bumi Aksara.

Helfert, Erick A. 1997. Tehnik analisis keuangan, Edisi ke-8 , Jakarta: Erlangga

Irham Fahmi. 2012. Manajemen Kinerja. Bandung: Alfabet

Ikatan Akuntan Indonesia (IAI), 2002. Standar Akuntansi Keuangan. Jakarta: Salemba Empat

Jaja Suteja. 2012. Sofyan Syafri Harahap. 2011. Teori Akuntansi, Edisi Revisi 2011. Jakarta: Rajawali Press

J Supanto. 2007. Tehnik Sampling Untuk Survei dan Eksperimen. Jakarta: Raja Grafindo Persada

Kasmir. 2003. Bank Dan Lembaga Keuangan Lainnya. Jakarta: PT RajaGrafindo Persada

Kasmir. 2008. Manajemen Perbankan. Edisi Revisi 2008. Jakarta: PT RajaGrafindo Persada

Kasmir. 2011. Dasar-dasar Perbankan. Jakarta: PT Raja Grafindo Persada

Keown, Arthur J, David Scott, John Martin, Jay W Petty, 1999. Dasar-Dasar Manajemen Keuangan. Salemba Empat. Jakarta.

Komang Darmawan. 2004. Analisis Rasio Bank. Info Bank Juli 18-21 
Machfoez. 1996. Akuntansi Manajemen 2. Edisi 3 Yogyakarta: BPFE

Mamduh M Hanafi, Abdul Hakim. 2002. Analisis Laporan Keuangan. Yogyakarta: UPP AMK YKPN

Martono, Agus Harjito. 2010. Manajemen Keuangan. Edisi Ketiga, Yogyakarta: Ekonosia

M Manullang. 2014. Dasar-dasar Manajemen. Yogyakarta: Gajah Mada University Press

Munawir, S. 2002. Analisis Informasi Keuangan. Yogyakarta: Liberty Yogyakarta.

Munawir, S. 2007. Analisa Laporan Keuangan. Yogyakarta: Liberty .

Nachrowi Jalal, Hardius Usman. 2006. Pendekatan Populer dan Praktis Ekonometrika untuk Analisis ekonomi dan keuangan. Jakarta: FE UI

Nyoman Mindra Jaya, Neneng Sunengsih. 2009. Kajian Analisis Regresi Dengan Data Panel. Yogyakarta: UNY

O Gill, James. 2006. Dasar-Dasar Analisis Keuangan, Informasi Keuangan Untuk Semua Manajer. Jakarta: PPM

Priyatno Dwi. 2008. Mandiri Belajar SPSS, Yogyakarta: Mediakom

Priyatno Dwi. 2012. Cara Kilat Belajar Analis Data dengan SPSS 20, Edisi 1 Yogyakarta: Andi

Riyadi Slamet. 2006. Banking Assets And Liability Management. Jakarta: Lembaga Penerbit Fakultas Ekonomi Universitas Indonesia

Robert Anggoro. 2009. Metode penelitian komunikasi. Bandung: PT Remaja Rosdakarya

Safrani, ladzy. 2012. Manajemen dan Reformasi Pelayanan Publik Dalam Konteks Birokrasi Indonesia. Surabaya: Aditya Media Publishing

Salam Darma Setyawan. 2007. Manajemen Pemerintahan Indonesia. Jakarta: Djambatan

Santoso, Singgih. 2010. Statistik Multivarian. Jakarta : PT Elex Media Komputindo

Sigit Triandanu, Totok Budi Santoso. 2008. Bank dan lembaga Keuangan Lainnya. Jakarta: Salemba Empat Jakarta

Siswanto, H.B. 2005. Pengantar Manajemen. Bandung: Bumi Aksara

Sugiyono. 2004. Metode Penelitian Bisnis. Bandung: Afabeta
Sugiyono. 2006. Statistika Untuk Penelitian, Cetakan ke 7. Bandung: Afabeta

Sugiyono. 2010. Metode Penelitian Kuantitatif Kualitatif dan RnD. Bandung: Afabeta

Sugiyono. 2014. Memahami Metode Penelitian Kuantitatif. Bandung: Afabeta

Sofyan Syafri Harahap. 2006. Analisa Kritis Atas Laporan Keuangan. Jakarta: Rajawali Press

Sofyan Syafri Harahap. 2011. Teori Akuntansi, Edisi Revisi 2011. Jakarta: Rajawali Press

Suharsini Ari Kunto. 2010. Prosedur Penelitian Suatu Pendekatan Praktik. Jakarta: Rineka Cipta

Sutrisno. 2008. Manajemen Keuangan Teori Konsep dan Aplikasi. Yogyakarta: Ekonosia

Teguh Pudjo Mulyono. 1999. Analisis Laporan Keuangan Untuk Perbankan. Cetakan Keenam, Jakarta: Djambatan

Triandaru, Sigit dan Totok Budisantoso. (2008). Bank dan Lembaga Keuangan Lain. Jakarta : Salemba Empat

Widarjono Agus. 2007. Ekonometrika Teori Dan AplikasiUntuk Ekonomi Dan Bisnis. Yogyakarta: Ekonosia

Wing Wahyu Winarno. 2011. Analisis Ekonometrika dan Statistika Dengan Eviews, Edisi Ke 3. Yogyakarta : Unit Penerbit dan Percetakan (UPP STIM YKPN)

Ayuningrum, Anggrainy Putri. 2011. Analisis Pengaruh CAR, NPL, BOPO, NIM dan LDR Terhadap ROA. Skripsi tidak diterbitkan. Semarang : Program Sarjana Fakultas Ekonomi Universitas Diponegoro

Mawardi, Wisnu. 2005. Analisis Faktor-Faktor yang Mepengaruhi Kinerja Keuangan Bank Umum di Indonesia (Studi kasus Pada Bank Umum dengan total Asset Kurang Dari 1 Triliun). Jurnal Bisnis Strategi, (Online), Vol. 14, No. 1, (http://isjd.pdii.lipi.go.id , diakses 03 Oktober 2012).

Nusantara, Ahmad Buyung. 2009. Analisis Pengaruh NPL, CAR, LDR, dan BOPO Terhadap Profitabilitas Bank (Perbandingan Bank Umum Go Publik dan Bank Umum Non Go Publik di Indonesia Periode Tahun 2005-2007). Tesis tidak diterbitkan. Semarang: Program Studi Magister Manajemen Universitas Diponegoro.

Yuliani. 2007. Hubungan Efisiensi Operasional dengan Kinerja Profitabilitas pada Sektor Perbankan yang Go Publik di Bursa Efek Jakarta. Jurnal Manajemen \& Bisnis 
Sriwijaya, (Online), Vol. 5 No 10, (http://

digilib.unsri.ac.id, diakses 03 Oktober 2012)

Peraturan Bank Indonesia Nomor: 13/1/

PBI/2011. Tersedia di www.bi.go.id

Peraturan Bank Indonesia Nomor: 15/12/

$\mathrm{PBI} / 2013$. Tersedia di www.bi.go.id

Peraturan Bank Indonesia Nomor: 3/22/

PBI/2001. Tersedia di www.bi.go.id

Tabeldfdan tahun 2006, http://junaidichaniago_ wordpress.com 